\title{
Parasites and hepatic histopathological lesions in lisa (Mugil incilis) from Totumo mash, North of Colombia
}

\author{
Parásitos y lesiones histopatológicas en lisa \\ (Mugil incilis) de la Ciénaga del Totumo, norte de Colombia
}

\author{
Jesús Olivero V, ${ }^{1}$ Ph.D, Bárbara Arroyo S, ${ }^{1}$ M.Sc, Ganivet Manjarrez $\mathrm{P}^{1}{ }^{1}$ M.Sc.
}

\begin{abstract}
${ }^{1}$ University of Cartagena. Faculty of Pharmaceutical Sciences. Environmental and Computational Chemistry Group. Campus of Zaragocilla. Cartagena Colombia. *Corresponding author: joliverov@ unicartagena.edu.co
\end{abstract}

Recibido: Julio de 2011; Aceptado: Diciembre de 2011.

\begin{abstract}
Objective. To assess the levels of parasitism by nematodes and trematodes, as well as the hepatic histopathological alterations present in Mugil incilis (Lisa) from Totumo marsh, North of Colombia. Materials and methods. Between July 2004 and June 2005, 500 fish were collected at Totumo Marsh $\left(75^{\circ} 16^{\prime} \mathrm{W}\right.$ and $\left.10^{\circ} 44^{\prime} \mathrm{N}\right)$, North of Colombia. Morphometric and parasitic parameters were determined for each specimen, and the hepatic histopathological status of the liver was assessed by analyzing liver slides stained with hematoxylin and eosin. Results. Nematode larvae isolated from Mugil incilis corresponded to Contracaecum spp. Parasite prevalence was $60.49 \%$. Parasitic mean abundance and mean intensity were $4.8 \pm 1.05$ and $7.02 \pm 1.49$, nematodes per fish, respectively. The correlation between nematode mean abundance and fish length was significant and positive $(r=0.525$, $p<0.0001)$, but negative for condition factor $(r=-0.109, p=0.014)$. Hepatic histopathological analysis revealed the presence of encapsulated trematode larvae as the main finding. However, the presence of inflammation, granulomas, steatosis and necrosis, were also registered as secondary alterations. Conclusions. Lisas collected at Totumo Marsh are parasitized with nematodes and trematodes. These fish have different histopathological lesions in the liver tissue, being the most important the presence of trematode encapsulated cyst that generate inflammatory reactions, and negatively correlate with morphometric markers of fish health.
\end{abstract}

Key words: Anisakiasis, fishes, nematode, trematode, zoonoses (Source: $C A B$ ).

\section{RESUMEN}

Objetivo. Evaluar los niveles de parasitismo por nemátodos y tremátodos, así como las alteraciones histopatológicas hepáticas presentes en Mugil incilis (Lisa) de la Ciénaga del Totumo, Norte de Colombia. Materiales y métodos. Entre Julio de 2004 y Junio de 2005, 500 peces fueron recolectados en la ciénaga del Totumo $\left(75^{\circ} 16^{\prime} \mathrm{W}\right.$ y $\left.10^{\circ} 44^{\prime} \mathrm{N}\right)$, norte de Colombia. Índices morfométricos y parasitarios fueron determinados para cada espécimen, y el estatus histopatológico hepático fue evaluado analizando cortes de hígado teñidos con hematoxilina y eosina. Resultados. Los nemátodos aislados 
de Mugil incilis correspondieron a Contracaecum spp. La prevalencia del parásito fue $60.49 \%$. La abundancia media y la intensidad media parasitaria fueron $4.8 \pm 1.05$ y $7.02 \pm 1.49$, larvas por pez, respectivamente. La correlación entre la abundancia media de nemátodos y la longitud de las lisas fue significativa y positiva $(r=0.525, p<0.0001)$, pero negativa para el factor de condición $(r=-0.109, p=0.014)$. El análisis de la histopatología hepática reveló la presencia de larvas encapsuladas de tremátodos, como el hallazgo principal. Sin embargo, la presencia de inflamación, granulomas, esteatosis y necrosis, también fueron registradas como alteraciones secundarias. Conclusiones. Las Lisas colectadas en la ciénaga del Totumo están parasitadas con nemátodos y tremátodos. Estos peces poseen diversas lesiones histopatológicas en el tejido hepático, siendo la de mayor importancia la presencia de quistes encapsulados de tremátodos los cuales generan reacciones inflamatorias, y correlacionan negativamente con marcadores morfométricos de salud en estos peces.

Palabras clave: Anisakiasis, nemátodos, peces, trematodos, zoonosis (Fuente: $C A B$ ).

\section{INTRODUCTION}

Parasites from the Ascaridoidea superfamily (Anisakidae and Raphidascarididae) are common in marine mammals, invertebrates, fish-eating birds (1-3), and teleostean fish worldwide $(4,5)$.

The presence of larval stages of Anisakid nematodes in fish is a problem for commercial fishing industries due to the potential risk of transmission of zoonotic diseases such as anisakiasis (6-8), and foodborne allergenicity $(9,10)$. Currently, fish diseases, in particular those caused by parasites, constitute one of the most important problems and challenges confronting fish farming (11). This occurs because parasitism can be a critical factor contributing to fish mortalities (12), and in less worst case scenarios, it may induce severe histological changes in fish organs such as gills, liver and gonads. These lesions are useful as sensitive and reliable indicators of the health of wild fish populations (13).

In Northern Colombia, Lisa (Mugil incilis) is an economically important fish species, and it has been found to be parasitized with nematodes in Cartagena Bay, as well as in Totumo marsh (14). Recently, trematodes such as Ascocotyle longa, have also been found infecting the liver of this fish in Cartagena Bay (15). The goal of this research was to document the histopathological lesions found in Mugil incilis from Totumo marsh.

\section{MATERIALS AND METHODS}

Study area. Totumo marsh is a waterbody considered unpolluted by industrial sources. It is located approximately $60 \mathrm{~km}$ north from Cartagena, Colombia $\left(75^{\circ} 16^{\prime}-\mathrm{W}\right.$ and $10^{\circ} 44^{\prime}-$ $N)$. It has an average depth of seven inches and a drainage area of 2100 ha. Its climate is predominantly tropical sub-humid with an average temperature of $28^{\circ} \mathrm{C}$, and a relative humidity of $75 \%$. The average monthly precipitation ranges from 60 to $100 \mathrm{~mm}$ (14).

Fish collection. A total of 500 specimens of Mugil incilis were captured with the aid of fishermen from July 2004 to June 2005, and transported on ice to the laboratory, where necropsies were immediately performed. The following physicochemical parameters for surface water were registered during sampling campaigns, using a $\mathrm{pH}$-meter, conductimeter and a field thermometer, respectively: $\mathrm{pH}$ $7.8 \pm 0.2$, conductivity $142.7 \pm 75.2 \mu \mathrm{S} / \mathrm{cm}$ and temperature $27.8 \pm 0.8^{\circ} \mathrm{C}$.

Morphometric analysis and larvae identification. Morphometric and parasite infestation measurements were performed for each fish specimen. Total length and weight, organ weight, and number of nematode larvae were recorded. Fish condition factor (CF) was calculated using the formula $\mathrm{CF}=100 \times \mathrm{W} / \mathrm{L} 3$, where $\mathrm{W}=$ total weight $(\mathrm{g}), \mathrm{L}=$ total length $(\mathrm{cm})$. Liver-, gill- and spleen-somatic indexes (HSI), were obtained as (OW/W) $\times 100$, where $\mathrm{OW}=$ organ weight $(\mathrm{g}),(16)$. These morphometric parameters are considered markers of general fish health $(17,18)$.

Nematodes were recovered, fixed, clarified and preserved. Preliminary nematode identification was based on keys previously published, and on morphological features suggested in the literature $(19,20)$. Prevalence (proportion infected), mean intensity (parasites per infected individual), and mean abundance (parasites per individuals examined) were determined according to methods used by Bush et al (21). 
Histopathogical analysis. Livers were stored in buffered formalin and processed for histopathological examination. From each block, paraffin sections $(5 \mu \mathrm{m})$ were stained with hematoxylin-eosin. The lesions were recorded including those non-specific related to inflammatory changes (infiltration for inflammatory cells and granulomatosis), steatosis, necrosis and melanomacrophage centers (MMCs), among others (22). The histopathological study was carried out by individually examining each sample under the light microscope, evaluating the prevalence of finding lesions in each sample.

Statistical analysis. Data are presented as mean \pm standard error. Data were evaluated for normality and variance homogeneity using Kolmogorov-Smirnov and Barlett tests, respectively. Spearman correlations between infection levels and biometric parameters were tested. Analysis of variance (ANOVA) was employed to evaluate differences among means for different months in a particular sampling station. When normality was not achieved, ANOVA was replaced by Kruskal-Wallis test. Differences between means were evaluated by Student's t-test. For all statistical analysis, the criterion for significance was $p<0.05$.

\section{RESULTS}

Morphometric parameters as well as nematode parasitic infection indices obtained for all sampled specimens are presented in table 1.

Table 1. Morphometric parameters and indexes of infection by Contracaecum spp. larvae in Mugil incilis captured from Totumo marsh, North of Colombia

\begin{tabular}{lc}
\hline \multicolumn{1}{c}{ Parameter } & Totumo marsh \\
\hline Fish number & 500 \\
Length $(\mathrm{cm})$ & $11.71 \pm 0.24$ \\
Weight $(\mathrm{g})$ & $30.54 \pm 1.63$ \\
Condition factor & $1.37 \pm 0.02$ \\
Hepato-somatic index (\%) & $0.01 \pm 0.0006$ \\
Spleen-somatic index (\%) & $0.005 \pm 2.5219$ \\
Gills-somatic index (\%) & $0.064 \pm 0.004$ \\
Nematode prevalence (\%) & 60.49 \\
Nematode mean abundance (\%) & $4.48 \pm 1.05$ \\
Nematode mean intensity (\%) & $7.02 \pm 1.49$ \\
\hline
\end{tabular}

Besides the relative small fish size $(11.71 \pm 0.24$ $\mathrm{cm})$, nematodes were found in $60.49 \%$ of all examined samples. Based on the presence of a prominent intestinal caecum extending near the nerve ring, three lips with a cephalic tooth between them, among other observed characters (21), the nematode larvae present in Lisa corresponded to the third larval state (L3) of Contracaecum spp. (Nematoda anisakidae) (Figure 1). Parasite size oscillated between 8 and $29 \mathrm{~mm}$ in length, with an average of $20.98 \pm 0.15 \mathrm{~mm}$. Nematodes larvae were usually found encapsulated below the intestinal mesenteries $(51.48 \%)$, spine $(27.23 \%)$, liver $(20.43 \%)$ and a small proportion within the muscle $(0.94 \%)$, this last possibly as a result of post-death migration.

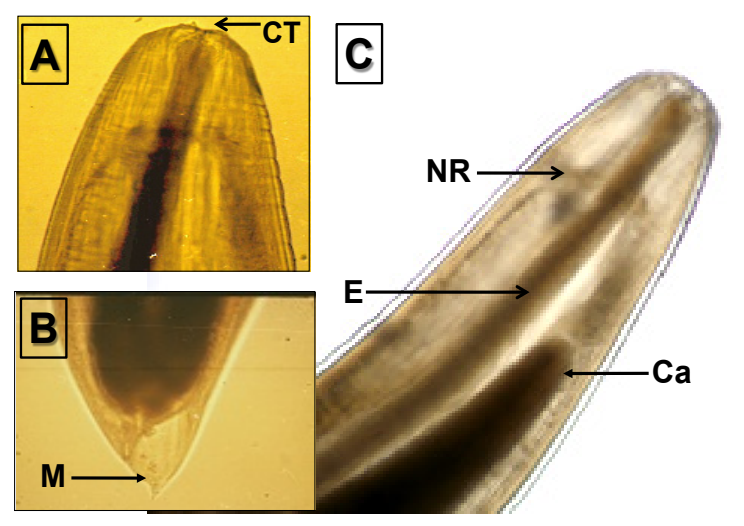

Figure 1. Morphologic characteristics of L3 anisakid larvae extracted of Mugil incilis captured from Totumo marsh, North of Colombia. (A). Anterior view, cuticular tooth (CT). (B). Posterior view, mucron (M). (C). Expanded anterior view showing the nervous ring (NR), the esophagus (E) and the intestinal caecum (Ca). Source: Environmental and Computational Chemistry Group. University of Cartagena.

Seasonal changes in the prevalence, mean intensity and mean abundance of nematodes in Mugil incilis are presented in figure 2 . The observed trend is similar for all three parameters, with greater values detected during September-October and May-June, corresponding to the rainy season, whereas the lowest values were obtained for JanuaryFebruary, during the dry season.

Correlation analysis for morphometric and parasitic parameters are shown in table 2. As expected, there was a strong and significant correlation between total host weight and length $(r=0.935, p<0.001)$. A positive and significant correlation was detected between nematode mean abundance and host length $(r=0.525$, $p<0.0001)$ and weight $(r=0.547, p<0.0001)$. Inverse and significant correlations were observed for nematode mean abundance and both host condition factor $(r=-0.109, p=0.014)$ and gill-somatic index $(r=-0.123, p=0.014)$. However, correlations were absent with internal organ somatic factors. 

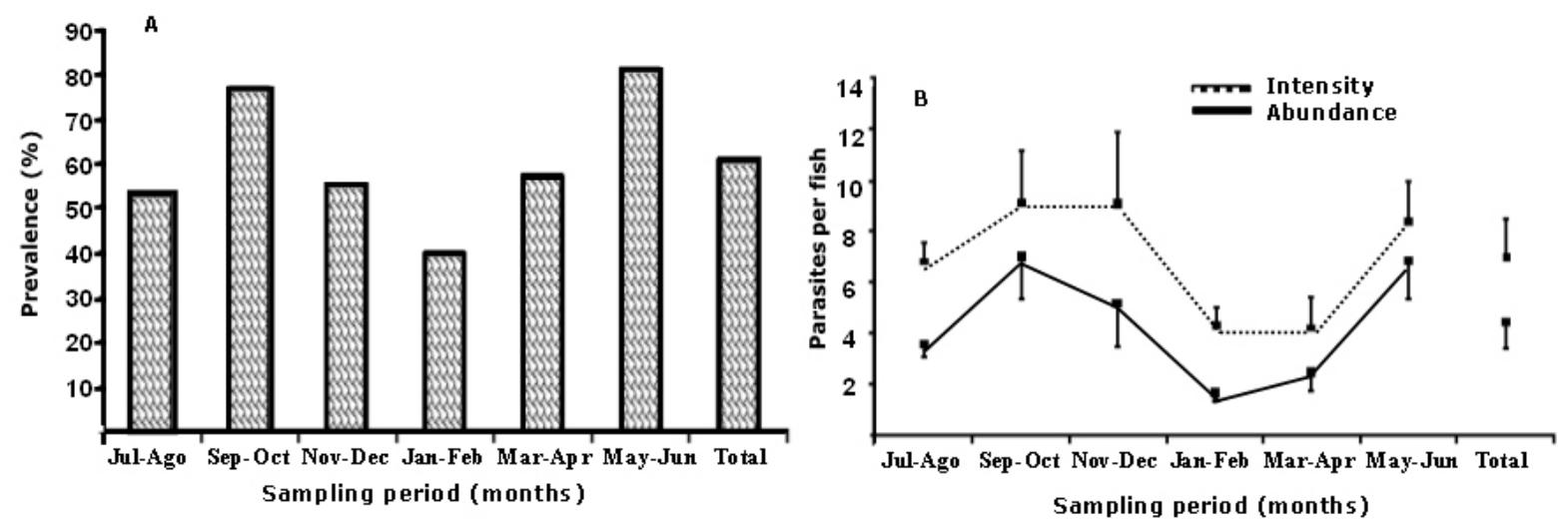

Figure 2. Seasonal prevalence (A), mean intensity and mean abundance (B) for Contracaecum spp. larvae in Mugil incilis.

Table 2. Spearman correlation between morphometric parameters and abundance of Contracaecum spp. larvae in Mugil incilis collected from Totumo marsh, North of Colombia.

\begin{tabular}{|c|c|c|c|c|c|c|c|}
\hline Parameters & Length & Weight & $\begin{array}{l}\text { Condition } \\
\text { factor }\end{array}$ & $\begin{array}{l}\text { Hepato-somatic } \\
\text { Index }\end{array}$ & $\begin{array}{c}\text { Spleen-somatic } \\
\text { index }\end{array}$ & $\begin{array}{l}\text { Gill-somatic } \\
\text { index }\end{array}$ & $\begin{array}{c}\text { Parasite } \\
\text { mean } \\
\text { abundance }\end{array}$ \\
\hline \multicolumn{8}{|l|}{ Length } \\
\hline Weight & $\begin{array}{c}0.935 \\
(p<0.001)\end{array}$ & - & & & & & \\
\hline $\begin{array}{l}\text { Condition } \\
\text { factor }\end{array}$ & $\begin{array}{c}-0.459 \\
(p<0.001)\end{array}$ & $\begin{array}{c}-0.181 \\
(p<0.001)\end{array}$ & - & & & & \\
\hline $\begin{array}{l}\text { Hepato-somatic } \\
\text { Index }\end{array}$ & $\begin{array}{c}0.009 \\
(p=0.858)\end{array}$ & $\begin{array}{c}0.046 \\
(p=0.357)\end{array}$ & $\begin{array}{c}0.035 \\
(p=0.486)\end{array}$ & - & & & \\
\hline $\begin{array}{l}\text { Spleen-somatic } \\
\text { Index }\end{array}$ & $\begin{array}{c}0.141 \\
(p=0.024)\end{array}$ & $\begin{array}{c}0.1814 \\
(p=0.004)\end{array}$ & $\begin{array}{c}-0.0265 \\
(p=0.672)\end{array}$ & $\begin{array}{c}0.016 \\
(p=0.795)\end{array}$ & - & & \\
\hline $\begin{array}{l}\text { Gill-somatic } \\
\text { Index }\end{array}$ & $\begin{array}{c}0.232 \\
(p<0.001)\end{array}$ & $\begin{array}{c}-0.363 \\
(p<0.001)\end{array}$ & $\begin{array}{c}-0.087 \\
(p=0.862)\end{array}$ & $-0.270(p<0.001)$ & $\begin{array}{c}-0.062 \\
(p=0.321)\end{array}$ & - & \\
\hline $\begin{array}{l}\text { Parasite } \\
\text { mean abundance }\end{array}$ & $\begin{array}{c}0.525 \\
(p<0.001)\end{array}$ & $\begin{array}{c}0.547 \\
(p<0.001)\end{array}$ & $\begin{array}{c}-0.109 \\
(p=0.014)\end{array}$ & $\begin{array}{c}0.021 \\
(p=0.666)\end{array}$ & $0.046(p=0.456)$ & $\begin{array}{c}-0.123 \\
(p=0.014)\end{array}$ & - \\
\hline
\end{tabular}

Histopathological findings detected in the liver of Mugil incilis collected in Totumo marsh are presented in table 3 and figure 3 . The most distinctive histopathological feature of the liver was the presence of encapsulated trematode cysts. Some of these formed granulome cysts characterized by the deposition of fibrous connective tissue and collagen. Others liver pathological alterations were infiltration of eosinophyls, inflammation, necrosis, and steatosis (Figure 3).
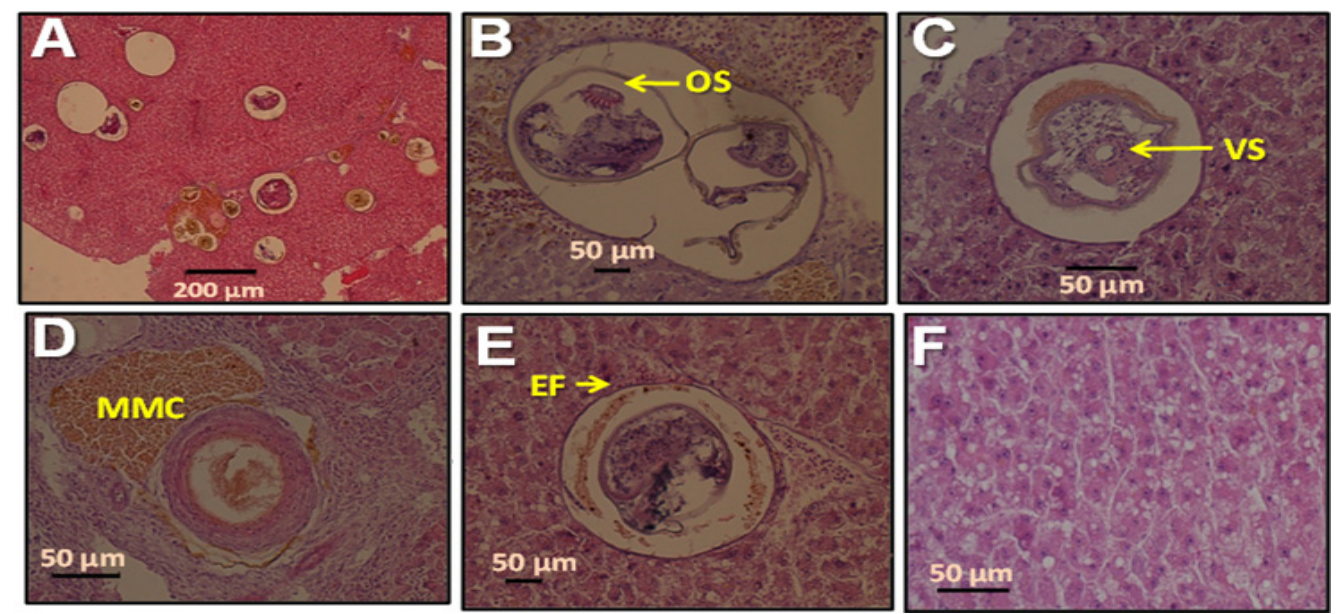

Figure 3. Paraffin-sections ( $5 \mu \mathrm{m}$ ) of liver tissue of Mugil incilis. (A). Multiple encapsulated cysts of trematodes in hepatics tissue. (B). Trematode cyst showing the oral sucker. (C). Trematode cyst displaying the ventral sucker. (D). Melano-macrophage center partially surrounding a cyst-related granuloma. (E). Eosinophyl infiltration (EF) associated to the connective tissue capsule in a trematode cyst. (F). Hepatic steatosis. Source: Environmental and Computational Chemistry Group. University of Cartagena. 
Table 3. Histophatological lesions in liver of Mugil incilis from Totumo marsh, North of Colombia.

\begin{tabular}{|c|c|c|c|c|c|c|}
\hline \multirow{2}{*}{ PARAMETER } & \multicolumn{6}{|c|}{ Sampling Period } \\
\hline & Jul/Aug & Sep /Oct & Nov/Dec & Jan/Feb & Mar/Apr & May/Jun \\
\hline Total number of examined fish & $N=16$ & $\mathrm{~N}=14$ & $\mathrm{~N}=16$ & $N=8$ & $\mathrm{~N}=15$ & $N=14$ \\
\hline Total encapsulated cyst counts/field ( $x$ 40) & $3.1 \pm 0.7$ & $3.2 \pm 0.5$ & $2.8 \pm 0.7$ & $3.9 \pm 1.1$ & $3.3 \pm 0.4$ & $2.4 \pm 0.5$ \\
\hline Necrosis foci $(\%)$ & 6.3 & 0 & 18.8 & 37.5 & 13.3 & 21.4 \\
\hline Steatosis (\%) & 18.8 & 14.3 & 18.8 & 0.0 & 0.0 & 7.1 \\
\hline Granuloma (\%) & 31.3 & 7.1 & 18.8 & 62.5 & 13.3 & 7.1 \\
\hline
\end{tabular}

$\%$, Prevalence of histological lesions.

\section{DISCUSSION}

Prevalence of Contracaecum nematodes in Mugil incilis reported in this study (60.49\%) was similar to that published for the same species in Cartagena Bay (74.67\%),(14). In México, C. multipapillatum prevalences were found between $14.5 \%$ and $30 \%$ in Mugil cephalus (23).

For Mugil incilis, the positive relationship between intensity of nematode and length and weight found might be the result of a time of exposuredependent process. This observation has also been detected for other parasites infecting different fish species such as Austrodiplostomum compactum (Digenea) in Plagioscion squamosissimus (24), Sphincterodiplostomum musculosum in Cyphocharax gilbert (25), and Spatulifer maringaensis in Sorubim lima (26), among others. Condition factor (CF) and hepato-somatic index are screening indices that provide information about the general condition of fish, and those are useful to identify exposure/effects of potential contaminants, or data on energy reserves. The low negative and significant correlation observed between condition factor and parasite mean abundance could indicate that these nematodes are impacting fish health; perhaps by affecting food metabolism or inducing stress factors on fish.

This work has also shown that the liver of Mugil incilis is parasitized with trematode encapsulated cysts. A previous report on this species from Cartagena bay has suggested that this encapsulated trematode larvae is Phagicola longa (15). Histopathological examination revealed that trematodes were encapsulated by connective tissue in association with accumulation of lymphocytes and melanomacrophages, as previously described by others authors (22), with a host reaction to the larval presence characterized by fibroblast proliferation, which forms a capsule of concentric layers of connective tissue. This phenomenum has also been observed for metacercariae of the digenean Posthodiplostomum minimum in bluegill, Lepomis macrochirus (27).

The deposition of collagen layers and fibroblasts in the liver of Mugil incilis, probably is the result of a host defense reaction. In this study, most granulomes were linked to the presence of melano-macrophages centers (MMCs). These histological effects have been suggested as biomarkers for water quality in terms of lack of oxygen and chemical pollution (28). However, this process may also be the result of different stages of chronic inflammatory response to severe tissue damage or to a variety of infections.

There are not reported data showing that nematodes, in particular Contracaecum spp., or trematodes, could be producing zoonoses in human beings that eats Mugil incilis, only from Totumo marsh, but also from urban areas such as Cartagena and Barranquilla, where these fish are sold. However, the lack of information regarding fish parasitism, and the health hazards linked with fish consumption, could help to increase the risk of parasitic zoonoses in the area, as has been reported for Peru (29).

In addition, although fish-borne parasitic zoonoses have been focused on people from low- and middle-income countries. This problem is rapidly expanding because of globalization and migration, among other factors (30). Therefore, taking into account that these fish are currently used as a protein source for many people, it is suggested to implement sanitary measurements to avoid zoonoses. 


\section{REFERENCES}

1. Barson M, Marshall BE. First record of Contracaecum sp. (Nematoda: Anisakidae) in fish-eating birds from Zimbabwe. J S Afr Vet Assoc 2004; 75(2):74-78.

2. Li L, Xu Z, Zhang L. A new species of genus Hysterothylacium Ward et Magath, 1917 (Nematoda, Anisakidae) from Liparistanakae (Scorpaeniformes, Liparidae) from the Yellow Sea, China. Acta Parasitol 2007; 52:371-375.

3. Mattiucci S, Paoletti M, Solorzano AC, Nascetti G. Contracaecumgibsoni n. sp. and C. overstreeti n. sp. (Nematoda: Anisakidae) from the Dalmatian pelican Pelecanuscrispus (L.) in Greek waters: genetic and morphological evidence. Syst Parasitol 2010; 75(3):207-224.

4. Szostakowska B, Myjak P, Wyszynski M, Pietkiewicz $H$, Rokicki J. Prevalence of anisakid nematodes in fish from Southern Baltic Sea. Pol J Microbiol 2005; 54(Suppl): 41-45.

5. Santoro M, Mattiucci S, Paoletti M, Liotta A, Uberti BD, Galiero $G$ et al. Molecular identification and pathology of Anisakis pegreffii (Nematoda: Anisakidae) infection in the Mediterranean loggerhead sea turtle (Caretta caretta). Vet Parasitol 2010; 174(1-2):65-71.

6. Audicana MT, Kennedy MW. Anisakis simplex: from obscure infectious worm to inducer of immune hypersensitivity. Clin Microbiol Rev 2008; 21(2):360-379.

7. Shamsi S, Eisenbarth A, Saptarshi S, Beveridge I, Gasser RB, Lopata AL. Occurrence and abundance of anisakid nematode larvae in five species of fish from southern Australian waters. Parasitol Res 2011; 108(4):927-934.

8. Mattiucci S, Paoletti M, Borrini F, Palumbo M, Palmieri RM, Gomes V et al. First molecular identification of the zoonotic parasite Anisakis pegreffii (Nematoda: Anisakidae) in a paraffin-embedded granuloma taken from a case of human intestinal anisakiasis in Italy. BMC Infect Dis 2011; 11:82.
9. Moneo I, Caballero ML, Gomez F, Ortega E, Alonso MJ. Isolation and characterization of a major allergen from the fish parasite Anisakis simplex. J Allergy ClinImmunol 2000; 106(1 Pt 1):177-182.

10. Petithory JC. New data on anisakiasis. Bull Acad Natl Med 2007; 191(1):53-65.

11. Costello MJ. How sea lice from salmon farms may cause wild salmonid declines in Europe and North America and be a threat to fishes elsewhere. Proc Biol Sci 2009; 276(1672):3385-3394.

12. Aunsmo A, Bruheim T, Sandberg M, Skjerve E, Romstad S, Larssen RB. Methods for investigating patterns of mortality and quantifying cause-specific mortality in seafarmed Atlantic salmon Salmo salar. Dis Aquat Organ 2008; 81(2):99-107.

13. Stentiford GD, Longshaw $M$, Lyons $B P$, Jones G, Green M, Feist SW. Histopathological biomarkers in estuarine fish species for the assessment of biological effects of contaminants. Mar Environ Res 2003; 55(2):137-159.

14. Olivero-Verbel J, Baldiris-Avila R, ArroyoSalgado B. Nematode infection in Mugil incilis (Lisa) from Cartagena Bay and Totumo Marsh, north of Colombia. J Parasitol 2005; 91(5):1109-1112.

15. Galvan-Borja D, Olivero-Verbel J, BarriosGarcia L. Occurrence of Ascocotyle (Phagicola) longa Ransom, 1920 (Digenea: Heterophyidae) in Mugil incilis from Cartagena Bay, Colombia. Vet Parasitol $2010 ; 168(1-2): 31-35$.

16. Olivero-Verbel J, Caballero-Gallardo K, Arroyo-Salgado B. Nematode infection in fish from Cartagena Bay, North of Colombia. Vet Parasitol 2011;177(1-2):119-126.

17. Köhler HR, Sandu C, Scheil V, NagyPetrica, EM, Segner H, Telcean I, Stan G, Triebskorn R. Monitoring pollution in river Mures Romania. Part III: biochemical effect markers in fish and integrative reflection. Environ Monit Assess 2007; 127:47-54. 
18. Yeom DH, Lee SA, Kang GS, Seo J, Lee SK. Stressor identification and health assessment of fish exposed to wastewater effluents in Miho Stream, South Korea. Chemosphere 2007; 67(11):2282-2292.

19. Shih HH. Parasitic helminth fauna of the cutlass fish, Trichiurus lepturus L., and the differentiation of four anisakid nematode third-stage larvae by nuclear ribosomal DNA sequences. Parasitol Res 2004; 93:188-195.

20. Martins M, Onaka E, Fenerick J. Larval Contracaecum sp. (Nematoda: Anisakidae) in Hoplias malabaricus and Hoplerythrinus unitaeniatus (Osteichthyes: Erythrinidae) of economic importance in occidental marshlands of Maranhao, Brazil. Vet Parasitol 2005; 127:51-59.

21. Bush AO, Lafferty KD, Lotz JM, Shostak AW. Parasitology meets ecology on its own terms: Margolis et al. revisited. J Parasitol 1997 83:575-583.

22. Marigomez I, Soto M, Cancio I, Orbea A, Garmendia L, Cajaraville MP. Cell and tissue biomarkers in mussel, and histopathology in hake and anchovy from Bay of Biscay after the Prestige oil spill (Monitoring Campaign 2003). Mar Pollut Bull 2006; 53(5-7):287-304.

23. Valles-Ríos ME, Ruiz-Campos G, GalavízSilva L. Parasite prevalence and intensity in Mugil cephalus (Pisces: Mugilidae), from Colorado River, Baja California, México. Rev Biol Trop 2000; 48(2-3):495-501.

24. Paes JV, Carvalho ED, da Silva RJ. Infection levels of Austrodiplostomumcompactum (Digenea, Diplostomidae) metacercariae in Plagioscion squamosissimus (Teleostei, Sciaenidae) from the Nova Avanhandava reservoir, Sao Paulo State, Brazil. J Helminthol 2010; 84(3):284-291.
25. Abdallah VD, de Azevedo RK, Luque JL. Community ecology of metazoan parasites of Cyphocharax gilbert (Quoy e Gaimard, 1824) (Characiformes: Curimatidae) from Guandu river, State of Rio de Janeiro, Brazil. Rev Bras Parasitol Vet 2005; 14(4):154-159.

26. Takemoto RM, Pavanelli GC. Aspects of the ecology of proteocephalid cestodes parasites of Sorubim lima (Pimelodidae) of the upper Parana River, Brazil: I. Structure and influence of host's size and sex. Rev Bras Parasitol Vet 2000; 60(4):577-584.

27. Mitchell LG, Ginal J, Bailey WC. Melanotic visceral fibrosis associated with larval infections of Posthodiplostomum minimum and Proteocephalus sp. in bluegill, Lepomis macrochirus Rafinesque, in central Iowa, U.S.A. J Fish Dis 1983; 6(2):135-144.

28. Agius C, Roberts RJ. Melano-macrophage centres and their role in fish pathology. J Fish Dis 2003; 26(9):499-509.

29. Cabrera R, Del Pilar M, Altamirano T. Anisakidosis a marine parasitic zoonosis: unknown or emerging in Peru? Rev Gastroenterol Perú 2004; 24(4):335-342.

30. Chai JY, Darwin-Murrell K, Lymbery AJ. Fishborne parasitic zoonoses: Status and issues. Int J Parasitol 2005; 35(11-12):1233-1254. 